\title{
Gesture Matematis Siswa dalam Menyelesaikan Masalah Fungsi
}

\author{
RIVATUL RIDHO ELVIERAYANI \\ Fakultas Ekonomi, Universitas Islam Lamongan. \\ E-mail: rivatulridho@gmail.com
}

\begin{abstract}
Abstrak:
Segala tindakan spontan siswa dalam menyelesaikan masalah matematika merupakan gesture. Penelitian terhadap tiga kelompok siswa yangmana setiap kelompok terdiri dari dua siswa semuanya menggunakan gesture berdasarkan klasifikasi McNeill. Gesture yang dilakukan sebanyak 53 gesture, diantaranya terdiri dari 13 gesture ikonik, 9 gesture metaforik dan 31 gesture deiktik. Gesture ikonik, metaforik dan deiktik ditemui dalam tiga cara baik itu disertai ucapan maupun tidak disertai ucapan. Pertama siswa menggunakan gesture ikonik, metaforik dan deiktik di atas kertas, kedua dilakukan diatas meja dan ketiga dilakukan di udara. Sesuai dengan hipotesis McNeill bahwa gesture matematis siswa memiliki gerakan-gerakan khusus untuk menjelaskan istilah- istilah matematika, dan gerakan ini menyerupai gerakan isyarat namun tidak semuanya mengacu pada gerakan isyarat.
\end{abstract}

Kata Kunci: pemecahan masalah, gesture, gesture ikonik, gesture metaforik, gesture deiktik.

\section{Pendahuluan}

Menyelesaikan masalah matematika merupakan proses yang perlu dimiliki siswa dalam pembelajaran matematika. Siswa dituntut untuk dapat mengembangkan kemampuan berpikirnya agar dapat lebih terampil dalam menyelesaikan masalah matematika. Peneliti banyak menemui siswa yang mengalami kesulitan dalam menyelesaikan tipe soal berbentuk soal cerita. Hal ini diperkuat oleh penelitian yang telah dilakukan oleh Croteau (2004) dan Chan, dkk (2006) bahwa siswa masih mengalami kesulitan saat memecahkan masalah matematika berbentuk soal cerita materi aljabar dan geometri.

Ketika siswa menyelesaikan masalah matematika, peneliti mencoba mengamati proses penyelesaian masalah yang dilakukan oleh siswa. Peneliti mulai tertarik dengan segala tindakan spontan yang dilakukan siswa dalam memecahkan masalah matematika. Salah satu penelitian tentang tindakan spontan ini diungkap oleh Caroline, dkk (2012) tentang Theories of Embodied Cognition, teori ini menjelaskan bahwa kemampuan kognitif seseorang berhubungan dengan tindakan dan persepsi dari orang 
tersebut. Theories of Embodied

Cognition 
inilah yang mendasari bahwa tubuh terlibat dalam proses berpikir yang dilakukan oleh seseorang. Ketika seseorang berhadapan dengan sebuah masalah, secara alamiah seseorang memikirkannya sebentar dan secara spontan menanggapi masalah tersebut dengan berinteraksi melibatkan gerakan tubuh mereka.

Gerakan-gerakan spontan inilah yang disebut sebagai gesture. Becvar, dkk (2008) berpendapat bahwa gesture merupakan semua gerakan tubuh, khususnya lengan dan tangan yang terintegrasi baik dengan ucapan maupun tidak dan digunakan sebagai alat untuk mengkomunikasikan sesuatu. Hosteter \& Alibali (2008) berpendapat bahwa gesture muncul dari persepsi dan simulasi motorik yang mendasari bahasa dan bayangan mental seseorang. Saat memecahkan masalah, siswa sering menggunakan gesture disertai dengan ucapan, hal ini digunakan untuk memperjelas penggunaan gesture kepada pendengar tentang apa yang sedang dipikirkannya (McNeill, 1992). Sehingga gesture sering nampak jika ada seseorang yang melihatnya.

Baru-baru ini penelitian yang menghubungkan antara gesture dan bahasa merupakan inovasi baru untuk sebuah paradigma dari kognisi yang diwujudkan. Gerakan seseorang merupakan bagian yang tak terpisahkan antara bahasa dan pikiran. Psikolog dan ahli bahasa David McNeill (1992) telah mengatakan bahwa bahasa dan gesture telah membentuk sebuah sistem yang terintegrasi dengan baik dalam berkomunikasi. McNeill juga menunjukkan bahwa bahasa dan gesture memiliki karakteristik yang berbeda namun efektif dalam mendukung sebuah makna dalam komunikasi. Sehingga gesture dapat berperan sebagai mediasi (perantara) antara pengguna gesture dengan pengamat, gambaran yang subjektif, menjelaskan sebuah hal, dan percakapan konvensional.

Saat siswa berdiskusi menyelesaikan masalah matematika, siswa melakukan komunikasi dengan rekannya baik dalam menjelaskan apa yang dipikirknnya ataupun melakukan sebuah gambaran dalam menjelaskan konsep matematika. Komunikasi yang dilakukan juga tidak lepas dari penggunaan gesture di dalamnya. Hal ini sesuai dengan penelitiam dalam beberapa tahun terakhir, terdapat sebuah badan penelitian empiris untuk melihat perananan gesture dalam melakukan, mengajar dan belajar matematika. Penelitian ini membahas topik mulai dari cara anak-anak menggunakan gesture dalam menghitung (Alibali \&diRusso, 1999); bagaimana siswa bekerja sama memahami berbagai jenis grafik (Moschkovich, 1996; Reynolds \& Reeve, 2002); penggunaan gesture dalam memecahkan masalah matematika (Alibali, dkk (1999); Rasmussen, Stephan \& Allen (2004); Edwards (2009); Radford, Edwards, \& Arzarello (2009); dan Francaviglia \& Servidio (2011)); Pemecahan masalah konservasi bilangan dan ekivalensi oleh Goldin-Meadow dan rekannya (Church \& Goldin-Meadow, 1986; Alibali \& Goldin-Meadow, 1993; 
Goldin-Meadow, Alibali, \& Church, 1993; dan Goldin-Meadow \& Alibali, 1995).

Berdasarkan penelitian-penelitian yang telah dilakukan peneliti ingin melakukan analisis deskriptif mengenai jenis gesture yang digunakan oleh siswa saat berdiskusi tentang konsep fungsi. Tujuan dari penelitian ini adalah untuk menggambarkan jenis gesture spontan yang dilakukan siswa dalam konteks matematika. Selain itu juga untuk menyelidiki hipotesis yang dikemukakan oleh McNeill saat difokuskan dalam konsep matematika.

\section{Metode}

Subjek penelitian ini terdiri dari enam siswa SMP kelas VIII. Selanjutnya subjek dibagi menjadi 3 kelompok secara heterogen. Diskusi terjadi selama 10 menit untuk menyelesaikan masalah soal cerita berkaitan dengan konsep fungsi yang dituangkan melalui sebuah grafik seperti di bawah ini:

Dua orang siswa kelas VIII, yaitu Koko dan Wachid terlihat sedang berdiskusi tentang sebuah grafik terkait materi relasi dan fungsi. (Perhatikan gambar di samping!) Jika sumbu $X$ padagrafik merupakan daerah asal suatu fungsi, Koko menganggap bahwa grafik tersebut merupakan representasi dari suatu fungsi. Namun, Wachid tidak setuju dengan koko. la berpendapat bahwa grafik tersebut bukan merupakan representasi suatu fungsi. menurutmu, siapakah yang benar? Kemukakan alasanmu!

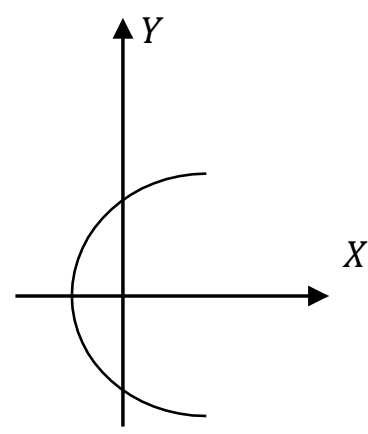

Data penelitian ini diambil dari rekaman audio-visual (video) siswa selama berdiskusi menyelesaikan masalah matematika secara kelompok. Selanjutnya dari hasil rekaman, peneliti menganalisa banyaknya gesture dan mengkategorisasikan variasi gesture yang dilakukan siswa dalam memecahkan masalah matematika. Analisis data mengikuti tahapan dari Johnson, B. \& Christensen L. (2004) yakni dilakukan dengan tekhnik transkripsi, segmentasi, kodding dan pengkategorisasian hingga penarikan kesimpulan.

\section{Hasil}

Dari hasil pengamatan yang telah dilakukan terhadap tiga kelompok, Tiga kelompok subjek terpilih berasal dari kelompok siswa berkemampuan tinggi dengan siswa berkemampuan sedang, siswa berkemampuan sedang dengan siswa berkemampuan sedang dan siswa berkemampuan sedang dengan siswa berkemampuan rendah. Terdapat sebanyak 53 geture yang dilakukan diantaranya terdiri dari gesture ikonik, gesture metaforik dan gesture deiktik. Tabel 1 dibawah ini menunjukkan distribusi dari tiga jenis gesture yang 
ditemukan serta presentase dari masingmasing jenis gesture.

\begin{tabular}{|c|c|c|}
\hline $\begin{array}{l}\text { Jenis } \\
\text { gesture }\end{array}$ & Banyaknya & Presentase \\
\hline $\begin{array}{l}\text { gesture } \\
\text { ikonik }\end{array}$ & 13 & $24,5 \%$ \\
\hline $\begin{array}{l}\text { gesture } \\
\text { metaforik }\end{array}$ & 9 & $17 \%$ \\
\hline $\begin{array}{l}\text { gesture } \\
\text { deiktik }\end{array}$ & 31 & $58,5 \%$ \\
\hline Total & 53 & $100 \%$ \\
\hline
\end{tabular}

Tabel 1. Distrubusi banyaknya gesture yang dilakukan

\section{Gesture Ikonik}

Gesture ikonik merupakan gesture yang menggambarkan hubungan kesesuaian dengan isi semantik pembicaraan. Gesture ikonik menggambarkan entitas konkret atau peristiwa, seperti melalui bentuk atau gerak lintasan tangan. Gesture ikonik terjadi ketika kedua siswa mendiskusikan tentang sebuah fungsi yang mengingatkan mereka tentang sebuah grafik yang saling berpotongan. Gesture tersebut dilakukan disertai dengan ucapan "seingatku kalau yang merupakan fungsi itu berpotongan dan sejajar." Pada saat itulah, mereka menggunakan tangan dan jari mereka untuk mengindikasikan bgaimana bentuk grafik yang saling berpotongan. Percakapan daan gesture yang dimaksud ditunjukkan pada Gambar 1 di bawah ini.

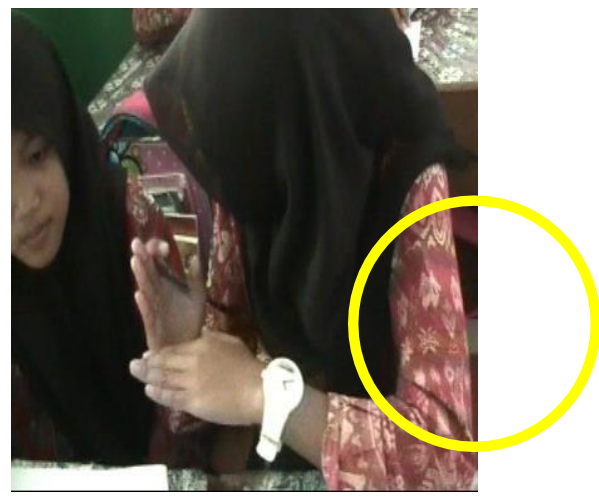

\section{Gambar 1. Gesture ikonik untuk menjelaskan garis berpotongan}

Sama halnya ketika kelompok lain mendiskusikam fungsi dengan representasi grafik maupun diagram mereka juga mengindikasikan konsep yang sedang dipikirkannya dengan menggerakkan tangan maupun jari-jari mereka secara spontan disertai dengan ucapan. Ketika mendiskusikan fungsi dengang diagram yang dikatakan "seingat saya fungsi itu bisa dibentuk dengan diagram panah yang saling menghubungkan antara satu bulatan dengan bulatan lainnya". Gesture yang menyertainya ditunjukkan pada gambar 2 di bawah ini.

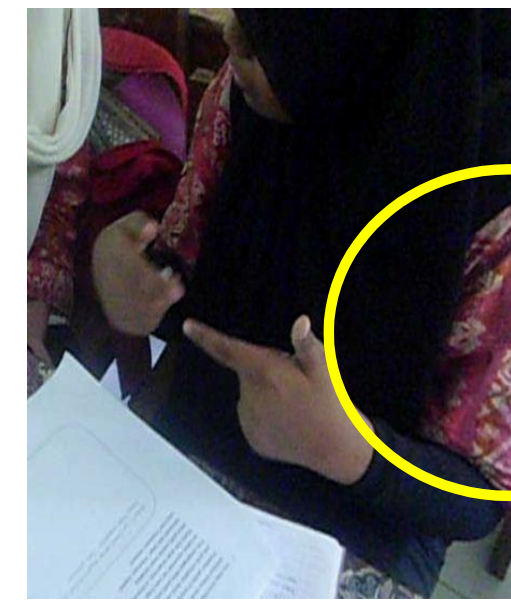

Gambar 2. Gesture ikonik untuk memjelaskan diagram panah fungsi 
Kalimat tersebut disertai dengan gesture yang dilakukan dengan mengaitkan kedua tangannya untuk merepresentasikan diagram panah antara domain dan kodomainsebuah fungsi.

Gerakan-gerakan yang dilakukan tersebut merupakan gesture ikonik yang artinya gerakan tersebut dilakukan oleh siswa sesuai dengan pengalaman yang pernah dilakukannya dan digunakan dalam menjelaskan konsep abstrak dalam matematika kepada rekan sebayanya. Hal itu dilakukan untuk mempermudah menyampaikan apa yang dipirkannya kepada rekan diskusinya. Dua gerakan yang diberikan peneliti sebelumnya menurut Edwards (2014) dapat dibagi dalam dua subcategori gesture yaitu gesture ikonik-fisik dan gesture ikoniksimbolik. Gesture ikonik-simbolik merupakan gesture yang mengacu pada gerakan-gerakan yang merujuk pada simbol atau grafik yang mana prosedur yang digunakan berkaitan dengan inskripsinya. Seperti yang ditunjukkan pada Gambar 1. Sedangkan gesture $i$ ikonik-fisik seperti yang disampaikan oleh McNeill's yaitu suatu gerakan konkrit atau fisik untuk menggambarkan sebuah hal, seperti gesture siswa pada Gambar 2.

\section{Gesture Metaforik}

Gesture metaforik adalah gesture yang menggambarkan isi semantik melalui kiasan tanpa bentuk fisik. Berbagai macamistilah dan frasa yang terkait dengangerakan metaforis, hal ini dapat dikatakan sebagai gerakan abstrak yang tidak memiliki makna secara nyata untuk menggambarkan peristiwa. Gerakan ini berhubungan dengan abstraksi matematika. Gambar 3 di bawah ini menunjukkan contoh salah satu gesture metaforik. Gesture ini muncul ketika keduanya saling berdiskusi dan menemukan perbedaan pendapat pada kesimpulan yang diperolehnya. Salah satu rekannya memberikan gambaran tentang apa itu titik potong pada sebuah "koordinat". Dalam kasus ini,siswa memberikan gambaran dengan membentangkan tangan kanannya dan menggerakkan tangan kirinya seperti menunjuk ke arah tangan kanan yang sedang dibentangnya (mungkin hal ini dimaksudkan sebagai bentuk koordinat titik pada sebuah grafik).

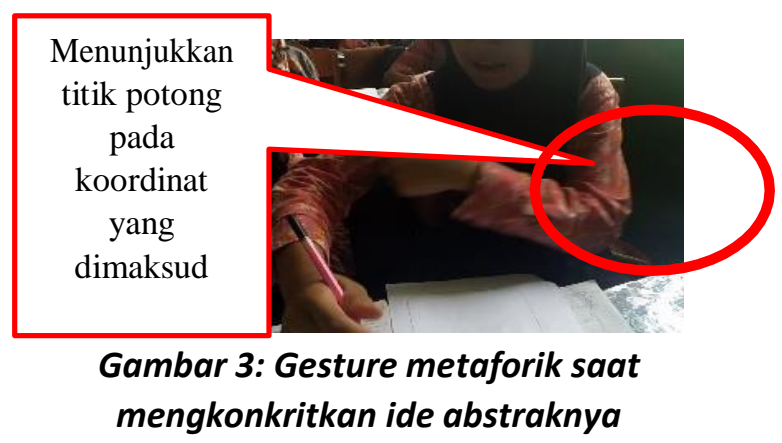

Gesture metaforik yang muncul pada kelompok lain yaitu saat salah satu rekan diskusinya tidak memahami masalah yang diberikan. Pada lembar tugas terdapat kata "representasi", salah satu siswabertanya tentang apa makna representasi yang dimaksud dalam lembar tugas tersebut. Selanjutnya rekan diskusinya menjelaskan makna tersebut diawali dengan menaikkan dan membuka semua tanggannya kemudian membuat lintasan ke samping serta membuat lintasan melingkari semua 
grafik sebanyak dua kali di atas kertas dengan jari tengah tanggan kanannya. Seperti yang terlihat pada gambar 4 di bawah ini.

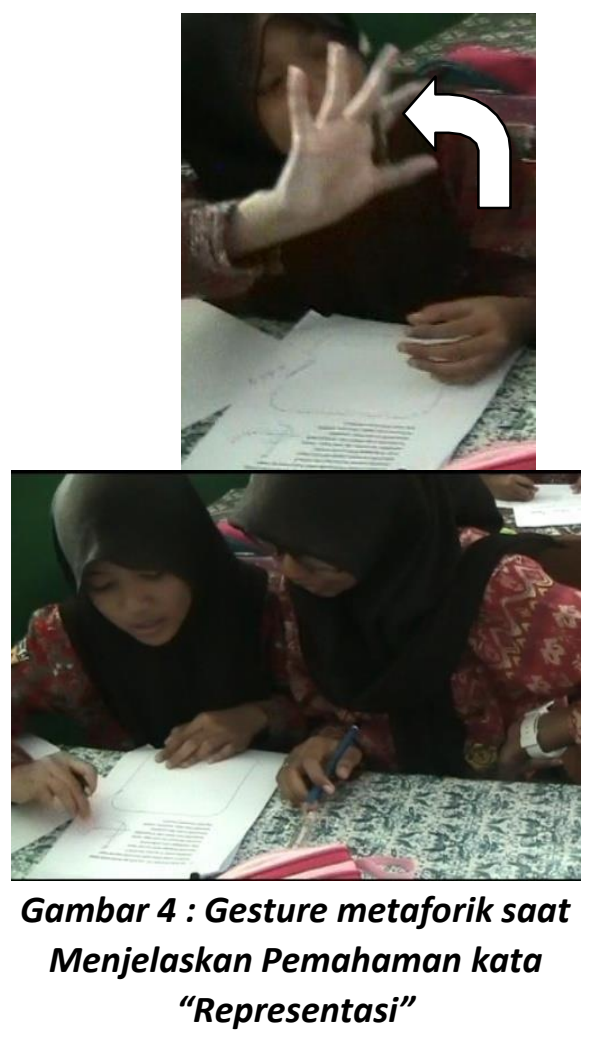

Gesture metaforik ini sangat menarik, karena mereka melakukan gerakan yang mengartikan bahwa sebuah penggambaran dari "representasi" grafik dalam matematika. Sampai-sampai kata tersebut harus dijelaskannya dalam perbincangan lain untuk mempermudah memahami apa yang dimaksud pada masalah yang sedang mereka hadapi.

\section{Gesture Deiktik}

Gesture deiktik merupakan gesture yang paling sering dilakukan siswa,baik saat siswa baru memahami masalah, sampai dengan siswa menyimpulkan hasil jawaban dari masalah yang sedang dihadapinya. Gesture deiktik merupakan gesture menunjuk. Sehingga peneliti menemukan gesture ini terkadang digunakan bersamaan dengan gesture ikonik maupun gesture metaforik. Seperti pada gambar 5 dibawah ini

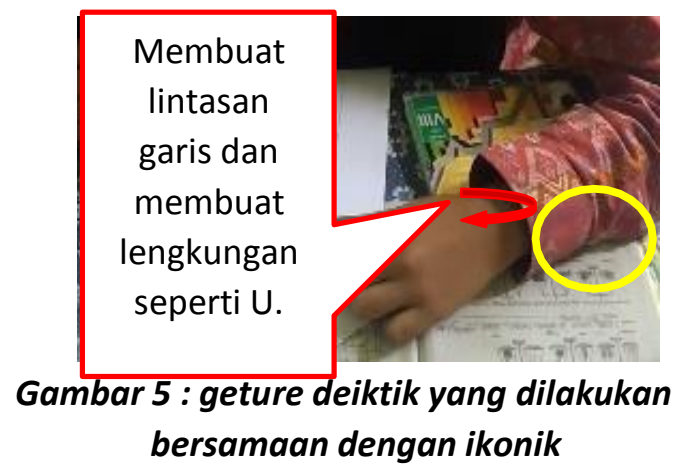

Hal ini wajar ditemui dikarenakan siswa mencoba untuk mengeksplorasi apa yang sedang dipikirkannya dengan berbagai macam gesture yang dianggapnya mudah untuk menyampaikan segala informasi yang sedang dipikirkannya. Hal ini sejalan dengan pendapat yang dikemukakan oleh Alibali \& Nathan (2011) bahwa gesture menunjuk yang dilakukan secara bersamaan atau serempak secara khusus efektif untuk mereduksi perhatian yang terpecah karena informasi diintegrasikan baik dengan leluasa maupun untuk sementara. Hal itu juga dapat membantu pengguna gesture untuk mengatur beban memori kerjanya saat berpikir untuk memecahkan masalah matematis dan memberikan penjelasan kepada lawan bicaranya. Selain itu argumentasi Francaviglia \& Servidio (2011) juga menguatkan bahwa siswa akan menggunakan beragam gesture sebagaimana persepsi pengetahuannya yang berguna sebagai strategi untuk menciptakan representasi pemikiran 
mereka dalam menghadapi masalah matematika.

Data hasil penelitian menunjukkan bahwa dalam memecahkan masalah matematis yang diberikan oleh peneliti, siswa melakukan variasi gesture. Variasi gesture yang dilakukan siswa dapat digolongkan berdasarkan klasifikasi yang dilakukan oleh McNeill (1992) mengenai gesture proporsional. Jenis gesture proporsional tersebut terdiri dari gesture ikonik, gesture metaforik dan gesture deiktik. Selanjutnya gesture ikonik dibagi lagi menjadi dua sub kategori yaitu gesture ikonik-fisik dan gesture ikoniksimbolik. Gesture deiktik merupakan gesture yang paling sering digunakan saat memecahkan masalah yang diberikan. Dari ketiga kelompok jumlah gesture deiktik yang dilakukan sebanyak 31dari 53 gesture yang dilakukan. Fakta ini sesuai dengan pernyataan yang diungkap oleh Alibali \& Nathan (2007) dalam salah satu penelitiannya diperoleh bahwa 56\% pembelajaran matematika menggunakan gesture, $21 \%$ diantaranya menggunakan gesture deiktik, 20\% diantaranya gesture representasional dan sisanya gesture menulis.

Data hasil penelitian menunjukkan bahwa gesture deiktik dilakukan siswa dengan dua cara, terkadang tanpa ucapan dan paling sering digunakan disertai dengan ucapan. Gesture deiktik yang dilakukan tanpa ucapan digunakan untuk dirinya sendiri sebelum menyampaikan apa yang dipikirkan kepada lawan bicaranya, hal ini sesuai dengan pendapat Alibali dan Nathan (2011) bahwa siswa mengekspresikan pengetahuan baru dalam bentuk gesture sebelum mereka menyampaikannya dengan perkataan. Sedangkan gesture deiktik yang digunakan bersamaan dengan ucapan digunakan untuk menunjukkan suatu hal kepada lawan bicaranya. Seperti yang dikatakan oleh McNeill (1992) bahwa gesture dan ucapan mengkombinasikan pengungkapan makna yang tidak sepenuhnya ditangkap oleh pembicara jikalau hanya dilakukan salah satu saja. Dengan kata lain gesture deiktik yang disertai dengan ucapan memberikan penegasan bagi pembicara untuk menyampaikan apa yang dipahaminya.

Dalam penelitian ini penggunaan gesture ikonik, metaforik dan deiktik ditemui dalam tiga cara baik itu disertai ucapan maupun tidak disertai ucapan. Pertama siswa menggunakan gesture ikonik, metaforik dan deiktik di atas kertas, kedua dilakukan diatas meja dan ketiga dilakukan di udara. Gesture ikonik yang dilakukan siswa diatas kertas ditujukan pada grafik. Gesture ini sering berbentuk lintasan bentuk, baik itu lintasan bentuk melingkar yang digunakan untuk merepresetasikan informasi yang dianggap penting dalam pikirannya, lintasan garis lurus untuk merepresentasikan sumbu $x$ sebagai daerah asal suatu fungsi dan lintasan grafik lengkung seperti huruf “ $U$ ” untuk merepresentasikan dengan jelas grafik fungsi kuadrat. Gesture yang dilakukan ini digunakan sebagai penggambaran objek yang sedang dipikirkan siswa saat berdiskusi dengan rekan kerjanya. 
Seperti yang dikatakan oleh McNeill (1992) bahwa matematika memiliki gerakan-gerakan khusus untuk menjelaskan istilah-istilah matematika, dan gerakan ini menyerupai gerakan isyarat namun tidak semuanya mengacu pada gerakan isyarat. Mengapa demikian? Karena dari ketiga kelompok yang mendiskusikan tentang konsep fungsi, ditemukan gerakan-gerakan yang hampir sama (konstan) untuk menggambarkan sebuah hal, baik seperti grafik fungsi kuadrat dan perpotongan titik. Sehingga salah satu tujuan dari penelitian ini bahwa untuk membuktikan hipotesis yang dikatakan oleh McNeill tentang konsep fungsi menunjukkan adanya gerakan yang khas dalam mempelajari sebuah konsep matematika.

Di bawah ini disajikan Tabel 1 mengenai protokol gesture siswa saat berdiskusi untuk menyelesaikan masalah yang berkaitan denga fungsi. simbol D artinya gesture deiktik yang digunakan, I adalah gesture ikonik dan $\mathrm{M}$ gesture metaforik.

Tabel 2. Protokol Gesture LIsaat

Memberikan Alasan Jawaban Setuju dengan Wachid

\begin{tabular}{|l|l|l|l|}
\hline \multicolumn{1}{|c|}{ Ucapan } & \multicolumn{1}{|c|}{ Gesture } & Jenis Gesture & Menit \\
\hline Ini kan gini & Dengan & D (gambar & $03: 21$ \\
& menggunakan & pada soal) & \\
pensil & I (koordinat & \\
mewakili jari & cartesius) & \\
& telunjuk & & \\
menunjuk & & \\
gambar dan & & \\
membuat & & \\
& lintasan tanpa & & \\
bekas & & \\
berbentuk dua & & \\
& garis, garis & & \\
pertama dari & & \\
arah atas ke & & \\
& bawah dan & & \\
garis kedua & & \\
dari kiri ke & & \\
kanan. & & \\
\hline
\end{tabular}

\begin{tabular}{|c|c|c|c|}
\hline Ucapan & Gesture & Jenis Gesture & Menit \\
\hline $\begin{array}{l}\text { Kamu ingat } \\
\text { deskriminan? } \\
\text { Kalau gini } \\
\text { bukannya itu? }\end{array}$ & $\begin{array}{l}\text { Dengan } \\
\text { menggunakan } \\
\text { pensil } \\
\text { mewakili jari } \\
\text { telunjuk } \\
\text { membuat } \\
\text { lintasan tanpa } \\
\text { bekas di udara } \\
\text { membentuk } \\
\text { garis } \\
\text { lengkung. }\end{array}$ & $\begin{array}{l}\text { I (representasi } \\
\text { grafik) }\end{array}$ & $03: 25$ \\
\hline $\begin{array}{l}\text { Bener gak } \\
\text { jawabanku? Tapi } \\
\text { yang ini? }\end{array}$ & $\begin{array}{l}\text { Dengan } \\
\text { menggunakan } \\
\text { pensil } \\
\text { mewakili jari } \\
\text { telunjuk } \\
\text { membuat } \\
\text { lintasan tanpa } \\
\text { bekas di meja } \\
\text { seperti bulatan } \\
\text { dan } \\
\text { membentuk } \\
\text { garis lurus di } \\
\text { tengah } \\
\text { bulatan. }\end{array}$ & $\begin{array}{l}\text { I(grafik } \\
\text { panah) }\end{array}$ & 03:39 \\
\hline $\begin{array}{l}\text { Bukannya kalau } \\
\text { fungsi itu harus } \\
\text { berbentuk gini }\end{array}$ & $\begin{array}{l}\text { Menggunakan } \\
\text { kedua } \\
\text { tanggannya, } \\
\text { tangan kanan } \\
\text { diarahkan ke } \\
\text { atas dan } \\
\text { tangan kiri } \\
\text { diarahkan ke } \\
\text { samping } \\
\text { kanan. }\end{array}$ & $\begin{array}{l}\mathrm{M} \\
\text { (perpotongan } \\
\text { garis) }\end{array}$ & 04:18 \\
\hline $\begin{array}{l}\text { Lah kalau ini } \\
\text { kan berbentuk } \\
\text { lengkung }\end{array}$ & $\begin{array}{l}\text { Menggunakan } \\
\text { jari telunjuk } \\
\text { membentuk } \\
\text { lintasan grafik } \\
\text { di udara } \\
\text { melengkung } \\
\text { seperti huruf } \\
\text { U. }\end{array}$ & $\begin{array}{l}\text { I (representasi } \\
\text { grafik fungsi } \\
\text { kuadrat) }\end{array}$ & 04:25 \\
\hline $\begin{array}{l}\text { Iya kan grafik } \\
\text { nya gini }\end{array}$ & $\begin{array}{l}\text { Menggunakan } \\
\text { jari telunjuk } \\
\text { membentuk } \\
\text { lintasan grafik } \\
\text { di udara } \\
\text { melengkung } \\
\text { seperti huruf } \\
\text { U. }\end{array}$ & $\begin{array}{l}\text { I (representasi } \\
\text { grafik fungsi } \\
\text { kuadrat) }\end{array}$ & 05:02 \\
\hline $\begin{array}{l}\text { Seingatku kalau } \\
\text { yang fungsi itu } \\
\text { berpotongan dan } \\
\text { sejajar }\end{array}$ & $\begin{array}{l}\text { Menggunakan } \\
\text { kedua } \\
\text { tangannya, } \\
\text { tangan kanan } \\
\text { dan kiri saling } \\
\text { bertumpu di } \\
\text { telapak tangan. }\end{array}$ & $\begin{array}{l}\mathrm{M} \\
\text { (representasi } \\
\text { grafik) }\end{array}$ & $05: 20$ \\
\hline $\begin{array}{l}\text { ini ada } \\
\text { deskriminannya }\end{array}$ & $\begin{array}{l}\text { Menggunakan } \\
\text { jari telunjuk } \\
\text { membentuk } \\
\text { lintasan grafik } \\
\text { di udara } \\
\text { melengkung } \\
\text { seperti huruf } \\
\text { U. }\end{array}$ & $\begin{array}{l}\text { I } \\
\text { (memperjelas } \\
\text { alasan grafik) }\end{array}$ & 06:04 \\
\hline Ini sejajar bukan & Menunjuk & D (tegak & $06: 22$ \\
\hline
\end{tabular}




\begin{tabular}{|l|l|l|l|}
\hline \multicolumn{1}{|c|}{ Ucapan } & \multicolumn{1}{|c|}{ Gesture } & Jenis Gesture & Menit \\
\hline tegak lurus & jawaban rekan & lurus) & \\
& diskusinya & & \\
& dengan & & \\
& $\begin{array}{l}\text { menggunakan } \\
\text { jari telunjuk } \\
\text { tangan kanan }\end{array}$ & & \\
& & \\
\end{tabular}

Eksplorasi makna dari gesture yang dihasilkan siswa dalam berpikir tentang sebuah konsep matematika akan banyak digali, karena topik gesture dalam bidang matematika diharapkan dapat memberikan inovasi terbaru dalam proses belajar mengajar. Tata cara berkomunikasi dengan menggunakan gesture diharapkan dapat membantu siswa lebih muda dalam memahami konsep matematika.

\section{Kesimpulan}

Berdasarkan hasil penelitian dan pembahasan, dapat disimpulkan bahwa selama berdiskusi menyelesaikan masalah matematika berkaitan dengan konsep fungsi. Gesture yang dilakukan sebanyak 53 gesture, diantaranya terdiri dari 13 gesture ikonik, 9 gesture metaforik dan 31 gesture deiktik. Gesture ikonik, metaforik dan deiktik ditemukan dalam tiga cara baik itu disertai ucapan maupun tidak disertai ucapan. Pertama siswa menggunakan gesture ikonik, metaforik dan deiktik di atas kertas, kedua dilakukan diatas meja dan ketiga dilakukan di udara. gesture digunakan sebagai alat untuk menarik perhatian dan memusatkan perhatian siswa selama berdiskusi memecahkan masalah karena siswa lebih tertarik memperhatikan argumentasi rekannya saat rekan diskusinya memunculkan gesture. Dengan memunculkan gesture siswa merasa terbantu dalam mengurangi beban kerjanya selama memecahkan masalah secara kelompok. Sesuai dengan hipotesis McNeill, gesture matematis siswa. bahwa matematika memiliki gerakan-gerakan khusus untuk menjelaskan istilah-istilah matematika, dan gerakan ini menyerupai gerakan isyarat namun tidak semuanya mengacu pada gerakan isyarat.

\section{Daftar Pustaka}

Alibali, M.W. \& DiRusso, A.A. 1999. The Function of Gesture in Learning to Count: More than Keeping Track. Cognitive Development, 14: 37-56.

Alibali, M.W. \& Goldin-Meadow, S. 1993. Gesture-speech Mismatch and Mechanisms of Learning: What the Hands Reveal about a Child's State of Mind. Cognitive Psychology, 25: 468-523.

Becvar, A., Hollan, J., dan Hutchins, E. 2008. Representational Gestures as Cognitive Artifacts for Developing Theories in a Scientific Laboratory. Ackerman, M.S., (eds) Resources, Co- Evolution and Artifacts: Theory in CSCW . Hal: 117143.

Caroline C, W., Walkington, C., Boncoddo, R., Srisurichan, R., Pier, E., Nathan, A., \& Alibali, M. 2012. Invisible Proof: The Role Of Gesture And Action In Proof. Journal of Memory and Languange, (Online), Vol.

43,

No. 3,

(http:/ / cwalkington.com?PME2012 Presentasion_V15.pdf, diakses Desember 2015) 
Chan, H., Tsai, P., Huang, T.Y. 2006.

Web-based Learning in a Geometry Course. Educational Technology \& Society, 9(2), pp.133-140.

Church, R.B. \& Goldin-Meadow, S. 1986. The Mismatch Between Gesture and Speech as an Index of Transitional Knowledge. Cognition, 23: 43-71.

Croteau, Ethan A.,Heffernan,Neil T. \& Koedinger,Kenneth R.2004.Why Are Algebra Word Problem Difficult?. Intelligent Tutoring Systems Lecture Notes in Computer Science, Vol. 3220, Hal: 240-250.

Edwards, L. 2009. Gesture, Conceptual integration and Mathematical Talk. International Journal for Studies in Mathematics Education, 1 (1): 33-46.

Francaviglia, M. \& Servidio, R. 2011. Gesture as a Cognitive Support to Solve Mathematical Problems. Psychology, 2 (2): 91-97.

Goldin-Meadow, S. \& Alibali, M.W. 1995. Mechanisms of Transfer: Learning with a Helping Hand. Psychology of Learning and Motivation, 33: 115157.

Hostetter, A.B. \& Alibali, M.W. 2008. Visible Embodiment:

Gestures as
Simulated Action.

Psychonomic

Bulletin \& Review. 15 (3): 495514

Johnson, B. \& Christensen, L. 2004. Educatioonal Research Quantitative, Qualitative, and Mixed Approaches Second edition. United States: Pearson Education, Inc.

McNeill, D. 1992 Hand and Mind: What Gesture Reveal about Thought. Chicago: Chicago University Press.

Moschkovich, J. (1996). Moving up and getting steeper: Negotiating shared descriptions of linear graphs. The Journal of the Learning Sciences, 5(3). 239-278.

Radford, L., Edwards, L., \& Arzarello, F. 2009. Introduction: Beyond words. Educational Studies in Mathematics, 70: 91-95.

Rasmussen, C., Stephan, M., \& Allen, K. 2004. Classroom Mathematical Practices and Gesturing. Journal of Mathematical Behavior, 23: 301-323.

Reynolds, F. \& Reeve, R. (2002). Gesture in collaborative mathematics problemsolving. Journal of Mathematical Behavior, 20. $447-460$ 